\title{
Materials and Prices of Sewage and Water Systems in Poland
}

\author{
Katarzyna Oszczapińska' \\ 1 Department of Civil and Environmental Engineering, Białystok University of Technology, ul. Wiejska 45A, \\ 15-351 Białystok, Poland \\ e-mail: k.oszczapinska@doktoranci.pb.edu.pl
}

\begin{abstract}
The costs for piping comparisons should include both the costs of the materials as well as construction. The construction costs depend on the trench depth, type of the soil, presence of rock, type of bedding material or location (urban and rural areas). The average costs of pipes were analysed in the article depending on material type, diameter and trench depth. The data relating to the pipe prices were collected on the basis of BISTYP cost base. Moreover, a preliminary analysis of sewage and water supply system cost was made on the basis of technical documentations published in Public Information Bulletins of communes. Recently, there has been a significant increase of interest in plastic pipes. Due to the low price and availability, these materials are most common used during piping both rural and urban areas.
\end{abstract}

Keywords: sewage systems, water systems, pipes, investment outlays on sewage systems

\section{INTRODUCTION}

The beginnings of the sewage system development date back to around $3500 \mathrm{BC}$, when for the first time stoneware sewage pipes were used. Later, the production of cast iron began in the 15 th century, followed by steel in the 18 th century. In the $1950 \mathrm{~s}$, further development enabled the production of ductile iron pipes, and in the 1990 s - from polymer concrete. In Poland, plastic pipes were used relatively late, in the early $70 \mathrm{~s}$; however, the production of PVC-U pipes started in Germany already in 1935. In 1945, PE-LD was used for the first time, then further development of technology took place in the 1950s with the use of PE-HD high-density polyethylene, PP polypropylene, and PE-X polyethylene cross-linked; in the late 1980s, a new generation of PE-HD, labelled as PE100 was launched [Angelakis et al. 2014; De Feo et al. 2014].

Water and wastewater management are the most subsidized environmental protection sectors in Poland and European Union. The sewage and water supply systems are one of the most important parts of municipal infrastructure. In order to analyse development in these areas, fixed assets created annually are evaluated. Among them, we can consider the water and sewage systems length and the percentage of people connected to these systems.

These networks should be designed for a long service life of at least 50 years. Such a long service life should increase the requirements for the use of such materials, production technology, and quality products to ensure product durability under varying soil and water conditions [Marzejon 2007].

In Poland, there is large disproportion between the water and wastewater system length. In 2018, there were almost $2 \mathrm{~km}$ of water supply system per $1 \mathrm{~km}$ of sewage system.

In addition, in $2017,92 \%$ of the citizens were connected to the water supply system $(96.6 \%$ in urban areas, and $85.1 \%$ in rural areas) (Figure 1), while only $70.5 \%$ of the population was connected to the sewage system $(90.2 \%$ in urban areas, and $40.8 \%$ in rural areas) (Figure 2).

It is caused mainly by the need to provide access to fresh water with the quality compatible with the Water Law from 18 July 2001 [Journal of Laws, no. 115, item 1229] for citizens and many times higher wastewater system's investment cost in comparison to the waterworks. 
Some studies have estimated the cost of sewer systems. Dogot et al. [2010] provided the statistical information on the costs of different sewerage system components as well as the investment costs for collective sewage systems constructed during 2000-2007 in the Walloon Region of Belgium. The statistical information on investment, operation and maintenance costs are particularly relevant. According to the Dogot research, average cost for a mixed sewage network built from 2000 to 2007 was $336 € / \mathrm{m}$, while for a separate sewage network it was $736 € / \mathrm{m}$.

\section{RESEARCH METHODS}

The data relating to the pipe's prices were collected on the basis of the BISTYP cost base. Multiple regression analysis was conducted to determine the correlation between pipeline's cost, trench depth and pipe's diameter depending on the material type and if the excavations were reinforced or not.
The investment costs of water and wastewater systems technical documentation obtained from the Public Information Bulletins of each communes were analysed. The pricings prepared on the basis of public auctions of Polish communes were updated in Norma Pro software connected with the actual InterCenBud cost base. Components like a wastewater treatment plant, lift stations and pumping main were not incorporated in the overall cost per $1 \mathrm{~m}$ of sewage and water supply system.

\section{MATERIALS USED IN SEWAGE AND WATER SYSTEMS}

The selection of pipes for specific applications must take into account many important parameters and material properties, because some pipes are intended for specific, selected technologies and their application in under conditions than those for which they are produced, can lead to serious mistakes, whether at the design stage or workmanship.

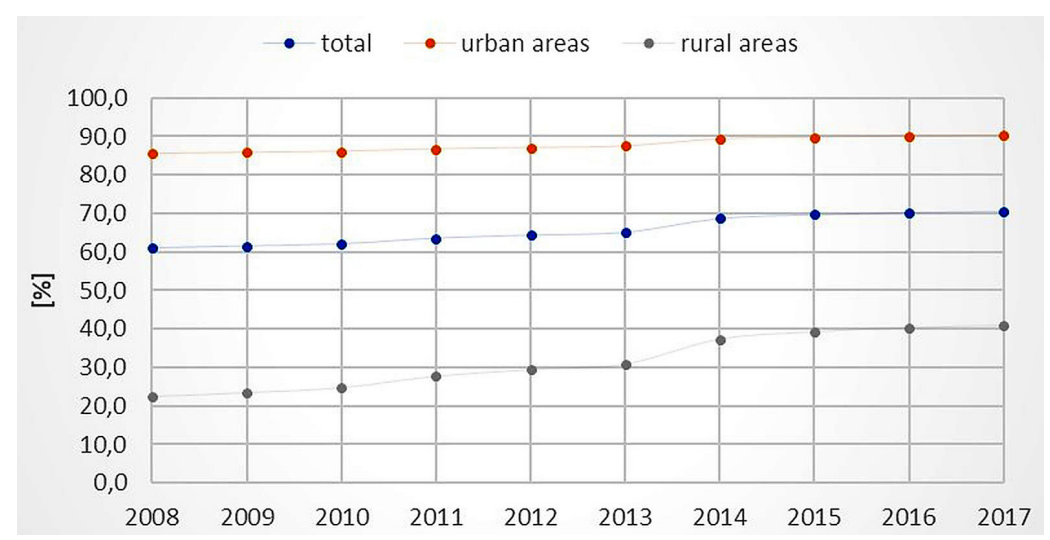

Figure 1. Percentage of citizens connected to the sewage systems in Poland in 2008-2017 (own study based on [Statistics Poland])

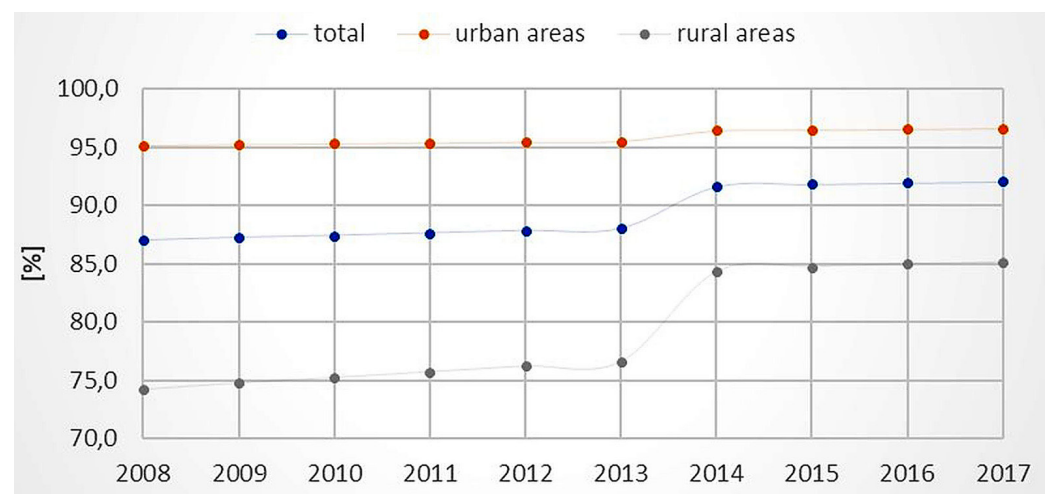

Figure 2. Percentage of citizens connected to the water supply systems in Poland in 2008-2017 (own study based on [Statistics Poland]) 


\section{Concrete}

The concrete used for the pipes production, due to its often extremely difficult operating conditions, is characterized by special properties such as resistance to aggressive environmental impact and high degree of water resistance. Polymer concrete is characterized by very good physical and chemical properties. A combination of resin and mineral quartz contributes to high compressive strength and bending [Florek 2011].

Polymer concrete pipes are characterized by high corrosion resistance, tightness, mechanical strength, durability and are also lighter than traditional concrete with the same strength [Kuliczkowski 2008].

\section{PVC}

Plastics are generated from synthetic resins of high molecular weight. The plastics used in the manufacturing of pipes belong principally to the polyvinyl chloride (PVC) and cellulose acetate types. The production of plastic pipes began with PVC pipes around 1935. PVC is used in water supply connections and water supply networks with diameters from 40 to $400 \mathrm{~mm}$, and since the late 1960s also in underground, gravitational, sewage piping, usually as a substitute for concrete. Diameters up to $630 \mathrm{~mm}$ are available. Polyvinyl chloride is an attractive alternative for use in sewer systems due to its high durability, light weight, high strengthto-weight ratio, long laying lengths, watertight joints and smooth interior surface. Together with simplicity in handling and connecting pipes, it led to the fact that PVC has become one of the most popular materials in the sanitary industry [Marsh 2009].
PE

Corrugated (smooth inside) PE-HD pipes are used in sewage systems, with a diameter of DN 100 to $300 \mathrm{~mm}$ as Duo pipes and DN 300 to $3000 \mathrm{~mm}$ as Spiro pipes, in sections of 6 and $12 \mathrm{~m}$ in length. Smooth walls pipes cause slight resistance to fluid flow, and external notches increase strength [Piechurski 2011].

\section{PP}

Polypropylene is closely related to PE, but it is considered to have better heat resistance. Current$1 y$, it is used especially for transporting hot industrial sewage, but also in the installations supplying hot utility water, as well as in water supply and domestic sewage disposal. The pipes with a diameter of 10 to $63 \mathrm{~mm}$ for water and up to $600 \mathrm{~mm}$ for sewage are most common [Lind 1998].

\section{WATER SUPPLY AND SEWAGE PIPELINES' PRICES IN POLAND}

Below are presented pipeline's prices calculated on the basis of BISTYP cost base (Table 1). The formulas were created using multiple regression. Trench depth $(h)$ and pipe's diameter $(d)$ were selected as independent variables, while unit cost of the pipeline in PLN per $1 \mathrm{~m}$ was chosen as a dependent variable. Moreover, unit costs (i) were determined by the pipe material type and if the excavations were reinforced or not $(r-$ reinforced, $u / r-$ unreinforced).

The unit cost included materials, manual trench preparing with and without reinforces, land disposal for landfill up to $1 \mathrm{~km}$, pipeline assembly and backfilling of the trenches. The unit cost in the case of pipelines made of PE is dependent on pipe's diameter, and the calculations relate to the

Table 1. Unit costs ( $i$ ) of water supply and sewage pipelines (own study based on [BISTYP])

\begin{tabular}{|c|c|c|c|}
\hline Material & Unit cost $[\mathrm{PLN} / \mathrm{m}]$ & & Coefficient of determination \\
\hline \multirow{2}{*}{ Concrete } & $\mathrm{i}_{r c}=1.4 d+229.68 \mathrm{~h}-537.41$ & (1) & $R^{2}=0.96$ \\
\hline & $\mathrm{i}_{u / r, c}=0.91 d+77.91 h-299.71$ & $(2)$ & $R^{2}=0.98$ \\
\hline \multirow{2}{*}{ PVC } & $\mathrm{i}_{r, P V C}=2.92 d+195.77 h-722.3$ & $(3)$ & $R^{2}=0.95$ \\
\hline & $\mathrm{iu}_{k, P V C}=3.08 d+341.24 h-733.12$ & $(4)$ & $R^{2}=0.97$ \\
\hline \multirow{2}{*}{ PE } & $\mathrm{i}_{r, P E}=318,22 e^{0,0036 d}$ & $(5)$ & $R^{2}=0.98$ \\
\hline & $\mathrm{i}_{u, P E}=219,87 e^{0,0043 d}$ & $(6)$ & $R^{2}=0.99$ \\
\hline \multirow{2}{*}{ PP } & $\mathrm{i}^{\mathrm{rPP}}=2.92 d+203.3 h-837.8$ & (7) & $R^{2}=0.94$ \\
\hline & $\mathrm{i}_{u / r, P P}=2.43 d+339.3 h-618.7$ & $(8)$ & $R^{2}=0.97$ \\
\hline
\end{tabular}


trenches with the depth up to $2 \mathrm{~m}$. Other cases provide trenches from 3 to $6 \mathrm{~m}$ depth. For concrete pipes diameter range was $200-1200 \mathrm{~mm}$, for PVC was 110-500, for PE pipes was 90-400 mm and for PP pipes 200-600.

\section{WATER SUPPLY AND SEWAGE SYSTEMS' INVESTMENT OUTLAYS IN POLAND}

On the basis of technical documentation for public auctions in Polish communes, preliminary analyses concerning water supply and sewage systems were prepared. The cost regarding to different systems were prepared in NORMA Pro Software.

Table 1 shows the percentage share in system cost, according to the network type and location divided into:

1. Preparation and demolition works

- Cutting and demolition of the paved areas and roadways

- Fences demolition

- Debris disposal

2. Surface recreation works

- Soil compaction

- Concrete, gravel and asphalts surfaces recreation

- Pavement and curbs reconstruction

3. Earthworks

- Measuring works, laying out pipeline route

- Performing excavation using specialized equipment and manually

- Preparing excavation reinforcements

- Trench drainage using wellpoints

- Backfilling of the trenches

4. Assembly works

- Bedding preparation for pipes

- Pipe-laying in the trenches
- Preparing drills through pipelines

- Installation of manholes and inspection chambers

- Leakage testing of water and sewer pipes and manholes

- Straightness of alignment and obstruction testing

\section{Materials cost}

The largest materials share in the sewage system cost was in the case of a vacuum network in rural areas (18\%), and when it comes to the sewage connection, highest materials share was in the investment of connections in rural areas (about $22 \%$ ). In turn, the lowest share in the sewage system cost was in the case of a pressure network in urban areas (6\%), and when it comes to the sewage connection, the lowest materials share was in the investment of connections in urban areas (about 9\%). In the case of water supply systems, higher materials share in investment outlays was in connections (Table 2).

The analysed urban area investments showed outlays within demolition, preparation and surface recreation works, which constituted largest contribution in outlays, regarding to the specifics of carrying out pipelines in road lanes. By contrast, investments in rural areas incurred the highest expenses mainly within assembly works (sewage systems), and within earthworks in the case of connections (Table 2).

The investment outlays for the construction of $1 \mathrm{~km}$ of a given type of network may differ as a result of different range of works, due to the conditions for conducting works, location of the investment (city / village), pipelines dimensions, materials and system's technology. These costs are variable the on a national scale and throughout the year, which results from the specificity of public auctions. Table 3 presents the estimated

Table 2. Percentage share in sewage and water supply system cost (own study based on [Technical documentation ...])

\begin{tabular}{|c|c|c|c|c|c|}
\hline System type & $\begin{array}{l}\text { Preparation and } \\
\text { demolition works }\end{array}$ & $\begin{array}{c}\text { Surface recreation } \\
\text { works }\end{array}$ & Earthworks & $\begin{array}{l}\text { Assembly } \\
\text { works }\end{array}$ & Materials \\
\hline Water supply (R) & - & - & 74 & 20 & 6 \\
\hline Water supply connection (R) & - & - & 55 & 44 & 1 \\
\hline Gravitational sewer (U) & 6 & 33 & 34 & 21 & 6 \\
\hline Sewer connection $(U)$ & 3 & 3 & 32 & 53 & 9 \\
\hline Gravitational sewer $(\mathrm{R})$ & - & 5 & 30 & 56 & 9 \\
\hline Sewer connection $(R)$ & - & - & 58 & 20 & 22 \\
\hline Pressure sewer (U) & 10 & 42 & 25 & 17 & 6 \\
\hline Vacuum sewer (R) & - & 3 & 39 & 40 & 18 \\
\hline
\end{tabular}


Table 3. Estimated cost of water supply and sewage systems in Poland - prices levels from 2019 (own study based on [Technical documentation...])

\begin{tabular}{|c|c|c|c|}
\hline System type & Material & Diameter [mm] & System's cost* $[\mathrm{PLN} / \mathrm{m}]$ \\
\hline Water supply (R) & $\mathrm{PE}$ & 90 & 370 \\
\hline Water supply connection (R) & PE & 32 & 264 \\
\hline Gravitational sewer $(U)$ & PVC & 200 & 1640 \\
\hline Sewer connection $(U)$ & PVC & 160 & 756 \\
\hline Gravitational sewer $(\mathrm{R})$ & PVC & 160 & 494 \\
\hline Sewer connection $(\mathrm{R})$ & PVC & 160 & 555 \\
\hline Pressure sewer (U) & PE & 90 & 1004 \\
\hline Vacuum sewer $(R)$ & PE & 160 & 404 \\
\hline
\end{tabular}

(R) - rural area

(U) - urban area

* - based on technical documentations for public auctions

costs of water supply and sewage systems in PLN per $1 \mathrm{~m}$ calculated on the basis of technical documentation from public auctions realized in recent years in Polish communes.

The most expensive connections turned out to be those made in urban area into the sewage system, where the unit cost reached 756 PLN per $1 \mathrm{~m}$ of the connection (Table 3). In turn, the sewer connections built in rural areas cost about $555 \mathrm{PLN} / \mathrm{m}$.

When it comes to the sewage systems, most high-priced investments were carried in urban areas, where the pipeline was made of PVC, and on average cost $1640 \mathrm{PLN} / \mathrm{m}$. In turn, the most lowpriced sewage systems within analysed were built rural areas with the vacuum technology (about 404 PLN/m).

In comparison to the sewage systems, water supply networks are less cost-consuming, both for pipelines and connection.

\section{CONCLUSIONS}

1. In Poland, there is a large disproportion between the water and wastewater system length, with almost $2 \mathrm{~km}$ of water supply system per of sewage system.

2. Nowadays, plastic pipes are the most popular material among contractors and investors, due to the simplicity in handling and connecting pipes, its low cost and availability.

3. The piping cost depends mainly on the material type, pipe diameter and foundation depth.

4. In the analysed cases, the cost of water and sewage systems largely depended on the investment location (urban/rural areas).
5. Within the considered sewage system types, the highest share of pipes cost was in the vacuum sewage system with about $18 \%$.

6 . The most expensive connections turned out to be those made in urban area into the sewage system, where unit cost reached 756 PLN per $1 \mathrm{~m}$ of the connection

7. The subject of sewage systems costing requires a more detailed analysis based on a larger number of tendering data.

\section{Acknowledgment}

The research has been carried out in the framework of project MB/WBiIŚ/20/2019 and financed from the Polish Ministry of Science and Higher Education's funds for science.

\section{REFERENCES}

1. Angelakis, A.N., Kavoulaki, E., Dialynas, M.G. 2014. Sanitation and stormwater and wastewater technologies in Minoan Era. In Evolution of Sanitation and Wastewater Management through the Centuries; Angelakis, A.N., Rose, J.B., Eds.; IWA Publishing: London, UK.

2. BISTYP (http://www.bistyp.pl/).

3. De Feo G., Antoniou G., Fardin H.F., El-Gohary F., Zheng X.Y., Reklaityte I., Butler D., Yannopoulos S., Angelakis A.N. 2014. The historical development of sewers worldwide. Sustainability 2014(6), 3936-3974.

4. Florek M. 2011. Concrete in the sewage system - important functional features. Wodociągi-Kanalizacja, 3/2011, 42-45 (In Polish).

5. InterCenBud (http://www.intercenbud.pl/).

6. Kuliczkowski A. 2008. Sewer pipes. T. 3. Rigid and elastic construction pipes. Kielce University of 
Technology Monograph, nr M4. Kielce (In Polish).

7. Lind Ch. 1998. Polypropylene for buried sewage piping systems. Plastic Pipes X Conference. The Institute of Materials UK. Gothenburg, Sweden, 1998.

8. Lind Ch. 2002. Polyethylene and Polypropylene in competitive sewerage systems. Dubai Plast Pro 2002, Dubai, U.A.E., April 15-17, 2002.

9. Marsh G. 2009. Composite pipes capture water and sewage markets. Reinforced Plastics 53(2009), $18-21$.

10. Marzejon K. 2007. Differences in a designing networks from plastic in comparison to a traditional materials (online). Available in the Internet: https:// www.prik.pl/wp-content/uploads/2017/07/K.MarzejonR\%C3\%B3\%C5\%BCnice-w-projektowaniu-sieci-z-tworzyw-sztucznych$\mathrm{w}-\mathrm{p}$ or $\% \mathrm{C} 3 \% \mathrm{~B} 3 \mathrm{wnaniu}-\mathrm{z}-\mathrm{sieciami-z-ma-}$ teria $\% \mathrm{C} 5 \% 82 \% \mathrm{C} 3 \% \mathrm{~B} 3 \mathrm{w}$-tradycyjnych.pdf. In Polish. (access: 20.08.2019).

11. Piechurski F.G. 2011. Selection of materials for the construction of the water and sewage network. Sewage networks (Part 2). Rynek Instalacyjny 9/2011, 52-55 (In Polish).
12. Satisistics Poland, Environment 2018, Statistical Analyses, Warsaw.

13. Statistics Poland: Local Data Bank (available online: https://bdl.stat.gov.pl/BDL/start).

14. Technical documentation for public service in Bagnice Małe, Mrągowo Commune (https://bipgmmragowo.warmia.mazury.pl/zamowienie/66/ budowa-sieci-kanalizacji-sanitarnej-w-m.-bagienice-male-gmina-mragowo-etap-ii.html) (access: 05.08.2019).

15. Technical documentation for public service in Jastrzębie, Poraj Commune (http://poraj.bip.net. $\mathrm{pl} /$ ?a=1548) (access: 05.08.2019).

16. Technical documentation for public service in Kopice, Stepnica Commune (http://bip.stepnica.pl/pobierz/2341) (access: 05.08.2019).

17. Technical documentation for public service in Suchodoły, Fajsławice Commune (https://ugfajslawice.bip.e-zeto.eu/index.php?type $\% 3 \mathrm{D} 4 \% 26$ name $\% 3$ Dbt29\%26func\%3Dselectsite\%26value \%255B 0\%255D\%3D1315) (access: 05.08.2019).

18. Water Law from 18 July 2001 (Dz.U. 115, 1229). 